\title{
"We" Human-and-Technology: When Technology does the Arts
}

\author{
hyunkyoung cho \\ ASPECT, Virginia Tech \\ hkcho@vt.edu
}

\begin{abstract}
This essay proposes "We" human-and-technology as the new human identity performed by the collaborative action of human and technology. Its aim is to open a new way for intersections of art, technology and humanities, through the political and aesthetic intimacy of human and technology in the collaborative action based interdependent perspective. The concept of "We" human-and-technology emphasizes the process of when the collaborative action of human and technology is performed. It focuses on two ideas: Enframing and the fetish. The former presents that the instrumental perspective uses the binary frame of "Us" versus "Them" as an instrument for ideology subordinating both humans and technology into the instrument. The latter demonstrates that the instrumental understanding of technology governs our senses through the fetish as blinded practices and beliefs distorting relations between human and technology.
\end{abstract}

Keywords-"We" human-and-technology; collaborative action; enframing; fetish

\section{INTRODUCTION -“WE” HUMAN-AND-TECHNOLOGY}

The identity of we humans is performed by collaborative action of human and technology. Like human-human communication, technology and humans act and react. The collaborative action of human and technology transforms the human condition. The new identity provoked by technology can be called as "We" human-and-technology. "We" humanand-technology considers the performing of "We" as the human species (our identity), rather than the definition of "I" as each single individual (my identity), in the collaborative action based interdependent perspective. "We" human-andtechnology emphasizes the process of when the collaborative action of human and technology is performed. It involves with relations of technological power embedded in the discourse of knowledge.

\section{POLITICS AND THE AESTHETIC OF "WE" FRIENDSHIP}

Michel Foucault stresses that technology establishes the "disciplinary framework" of modern society [1]. Technology is physical; for example, as it is found in the architecture of disciplinary institutions such as prisons, school, hospital, and Bentham's famous Panopticon. Yet to judge technology by its tool and productions is to miss its essential point. Technology has the performing characteristic which involves behavioral techniques; for example, the confession and the examination in a clinical, academic, or juridical setting. The aspect of performing enforces the production of "technologies of the self" to utilize, classify, isolate, and discipline "deviant" individuals. By the disciplinary and closed system of technology, we humans as individuals become "dividuals" in the "societies of control [2]."

Technology is a power; that one should decipher in it a network of relations, constantly in tension, in activity. The power of technology is exercised rather than possessed; it is not the "privilege," acquired or preserved, of the dominant class, but the overall effect of its strategic positions-an effect that is manifested and sometimes extended by the position of those who are dominated. Power and knowledge of technology directly imply each other. There is no power relation without the correlative constitution of a filed of knowledge, nor any knowledge that does not presuppose and constitute at the same time power relations. When technology plays in power and knowledge relations, we can capture a truth that there is the political and aesthetic intimacy between human and technology [3].

Technology is the evocative objects that underscore the inseparability of thought and feeling in our relationship to things. It provides a way to overcome "all authorities exercising individual control function according to a double mode; that of binary division and branding; and that of coercive assignment, of differential distribution [4]." Sherry Turkle notices the friendship of "We" human-and-technology in the evocative power of technology. Technology serves as a maker of relationship and emotional connection. She insists that, "the computer is emotional and intellectual companions that anchor memory, sustains relationships, and provokes new ideas [5]." We can consider computer technologies as companions to our emotional lives or as provocations to thought. The friendship presents that the focus of "We" human-and-technology is not on the technology's instrumental power-how fast computer calculates-but on the relationship as a friend in life experience: how the interaction between human and computer contributes to our daily life experiences as well as emotional and intellectual connections.

The friendship of "We" human-and-technology is intrinsically evocative. The evocative point is "what passes by us in the foreground and changing actions in the background. It is the playing erases the difference between foreground and background. The game the aeon plays with itself might be a mirror reflecting on we humans. This situation is a paradox of political and aesthetic friendship of "We" human-andtechnology. It recalls Friedrich Nietzsche meditation that, "Our desire for a friend is our betrayer [6]." Even though we humans 
create technology in order to see all things, what is shown by technology is the fact that we cannot see all things. The betrayal is the essence of friendship!

\section{ENFRAMING "WE"}

"We" human-and-technology constitutes the new focus in technology's continuous interrogation of the ground that supports our understanding of the efficacy of the arts. It reveals that the binary frame hides itself from the ways that supplementary knowledge necessarily depends on and requires exclusion. Moreover, the binary frame overlooks technological condition that highly autonomous computer programming or agents can customize a various emerging actions beyond the control of human. Through the exclusion of technology as a performer (a collaborator), it underestimates an eloquence of the collaboration of "We" human-and-technology. The instrumental understanding of technology is rooted in the human-subject centered dichotomy. In the binary frame, the relationship between human and technology is managed by the principle of utility; the fixed and permanent standards and measurements of productivity.

The binary frame forces the idea-based context-independent perspective. It subordinates both humans and technology into the instrument. The subordinate moment is "Enframing (Gestell)," as Martin Heidegger's conception [7]. Enframing indicates that the collaboration of "We" human-and-technology is enframed as a part of stockpile of available materials and personnel, and always ready for instrumental purpose. It thrusts "We" human- and-technology into the ordering, setting-upon and challenging nature, that is, busy instrumental circumstances. The human condition is shaped by the provocative exigencies of instrumental planning and control. Heidegger thus says that the binary frame is culmination of modern thinking. It is the human's hubris.

Enframing realizes the concept of inversion. According to Karl Marx, the inversion operates in the transference of usevalue and exchange-value. It discerns that Enframing is subject to not the form itself (the technology as a form of object in relation to we humans) but its social relation (the relationship of "We" human-and-technology misunderstood by the instrumental perspective). Here we encounter the true nature of use-value, since in Marx's work use-value serves only as an ideal point in relation to exchange value, to which everything is reduced. The use-value of technology indicates properties to satisfy human wants as the product of human labor. It exists simply as the result of human labor as well as an object with the specific use. There is no mysterious character in the usevalue. When technology steps into the social relation, it entails the collaborating with we humans. Here, technology takes over an exchange-value. This process shows that the exchange-value is the sociality of technology or its social relation. It is acquired through the collaboration of "We" human-and-technology. In this shifting from the use-value to exchange-value, the inversion happens.

Enframing reminds us of the mystery of commodity, in Marx's view. The collaboration of "We" human-andtechnology can be considered as a product of labor; it has a form as a kind of commodity, and it also involves social relations such as laws of demand and supply, the distribution in marketplace. Then the problem is that as soon as the product of labor assumes the form of commodity, the enigmatical character arises from its social relation. With Marx's knowledge, we can understand the reason why Jacques Lacan is willing to accept the notion that a computer thinks [8].
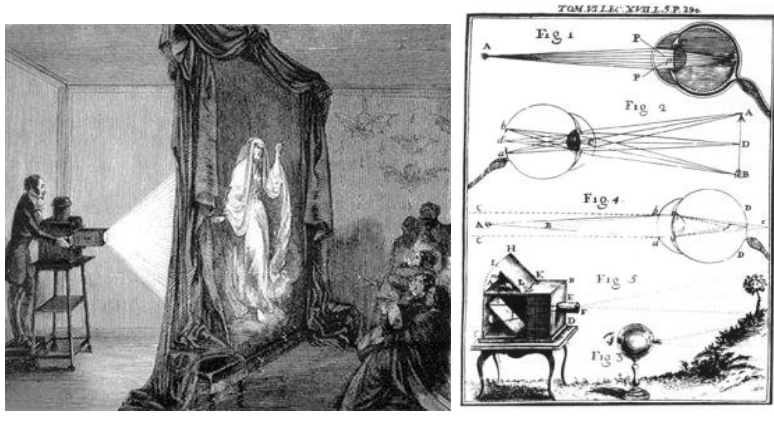

FIGURE I. COMPARATIVE DEPICTION OF HUMAN EYE AND CAMERA OBSCURA: EARLY EIGHTEENTH-CENTURY BOOK ILLUSTRATION. 1

Enframing of the instrumental perspective can be characterized by the metaphor of camera obscura creating an illusion through upside-down images. Marx notices the power of Enframing in the visual instrument, so he states that "if in all ideology men and their circumstances appear upside-down as in a camera obscura, this phenomenon arises just much from their historical life-process as the inversion of objects on the retina does from their physical life-process [9]." Camera obscura distorts the relation between our physical eyes and objects. This optical metaphor visualizes that consciousness projects an illusion by ideology, and here Enframing serves an instrument (apparatus) for ideology: as an instrument of social reproduction [10].

In the precise sense of the word "instrument," Enframing functions as the machine (tool/means) to produce and distribute the illusion of ideology, the false consciousness. In order to activate the reversibility of Enframing, Marx emphasizes that "consciousness can never by anything else than conscious existence, and the existence of men is their actual lifeprocess....men, developing their material production and their material intercourse alter, along with this their real existence, their thinking and the products of their thinking [11]." This expression may be read as a notion about the collaborative action-based context-dependent perspective, in order to integrate ideal and material understanding of the collaboration of "We" human-and-technology [12]. It implies that what we think about technology, its consciousness is not independent of material conditions. At the same time, it is necessarily referred to and conditioned by the real and lived relation in the actuallife process, that is, historical reality of society.

\footnotetext{
${ }^{1}$ This illustration was cited by Jonathan Crary's "The Camera Obscura and Its Subject," in Techniques of the Observer: On Vision and Modernity in the Nineteenth Century (New York: The MIT Press, 1992).
} 


\section{IV. "US" VERSUS "THEM"}

Marx's notion of the fetish enables to us to better understand the instrumental perspective. He writes that in order to understand the fetishistic inversion of instrumental perspective, we should pierce the heart of "the mist-enveloped regions of the religious world [13]." He compares the fetish to the religious or mythological form. In reality (human world), the product of labor acquires life. As the result of product of labor, the collaboration of "We" human-and-technology is immediately and actually related to the collaborative relationship of "We" human-and-technology. On the contrary, in religion or mythology, the product of labor as the collaboration of "We" human-and-technology is considered as a nature invested with subjective characters. The distance from reality is: that the contradiction of nature that religion seeks to explain evolves in the opposite direction to the social contradiction concealed by ideology.

Yet the key is that there is the fetish in the transposition between the religious world and the real human world. At this point, the fetish folds two aspects; on the one side, the religious world cannot entirely understand as long as it always uses analogy. On the other, it thus represents the real human world. The transposition (transference) between both aspects allows superior and mysterious powers as the fetish. This analysis affirms that the fetish of relations contributes to not the presentation of collaborative relationship of "We" human-andtechnology, but the representation of ideas of the binary frame of "Us" versus "Them." It treats ideas as if they are real subjects or beings endowed consciousness. The paradox is that the ideas appearing as supernatural subjects are external to consciousness.

The fetish problematizes, therefore, not "We" human-andtechnology who are mistaken about the reality, but the reality that deceives us by necessarily appearing under a form that disguises the real and live collaborative relationship in realm of the presentation. In this sense, we may understand Marx's insight that "the light from an object is perceived by us not as the subjective excitation of optic nerve, but as the objective form of something outside the eye itself [14]." It addresses that the instrumental perspective is blinded practices and beliefs, a means for transforming others rather than as an end in itself.

The interesting point is that the fetish of relations mainly sticks to the sense, in particular, our visibility. It connotes that the collaborative relationship of "We" human-and-technology cautions the blindness as the enthrallment by the fetish of discourse. It visualizes the metaphor of phantasmagoria. In Capital, Marx notes, "There is a definite social relation between men, that assumes, in their eyes, 'the fantastic form (dies phantasmagorische Form)' of a relation between things." 2 The phrase of 'the fantastic form (phantasmagoria form)' reveals that the fetish of relations regulates the senses (sensibility) through the binary of "Us" versus "Them": that is, fantasyframe.

\footnotetext{
2 The phrase translated here as, "the fantastic form" in German is "dies phantasmagorische Form.” Marx, Ibid., 72.
}

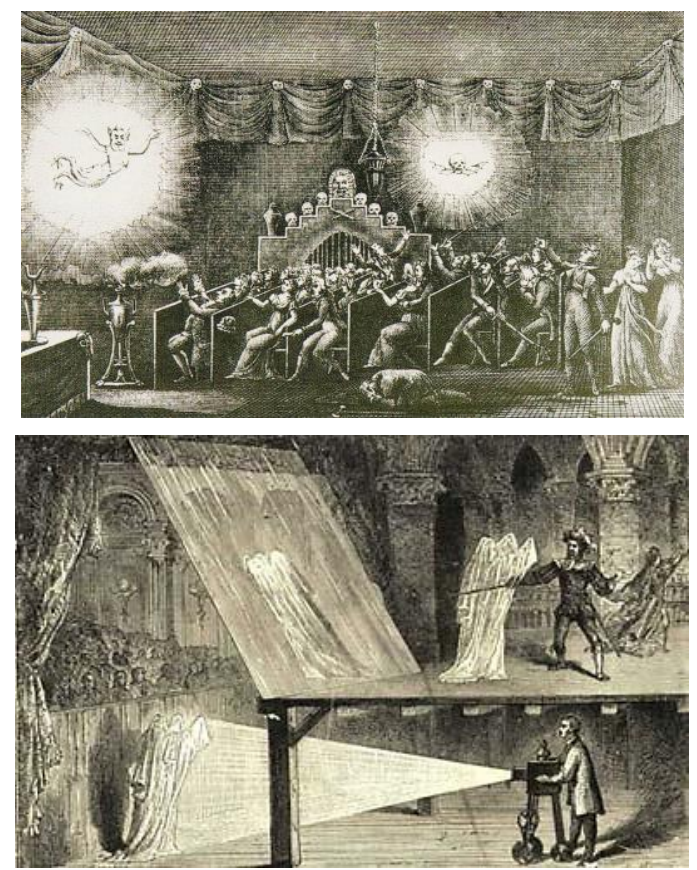

FIGURE II.

PHANTASMAGORIA SHOW [15].3

Phantasmagoria was the name of a type of popular and commercial entertainment in the illusion industry from the eighteenth to the mid-nineteenth century. It was a show (exhibition) of optical illusions using a various optical technologies. In those days, the optical illusion of phantasmagoria show was produced chiefly by means of a magic lantern in the darkened theater. Magic lanterns, invented in the seventeenth century, provided the means to tell stories in the projected images. It consists of a lamp and an arrangement of lenses to display images painted on the glass. Until motion pictures replaced it early in the twentieth century, it was a very popular form of mass entertainment, and achieved a commercial success. Interestingly, the darkened theater was first appeared in Richard Wagner's opera of Bayreuth at the nineteenth century. When a magic lantern was used in the darkness, the audience was entirely fascinated with new and strange images and the illusionary mood.

The main attraction of phantasmagoria show is a new sensibility introduced by projecting of images of supernatural apparitions and ghosts. The manipulation of the senses and the confusing between reality and fantasy is a model for the fetish of relation in the inversion of instrumental perspective. In other words, phantasmagoria show demonstrates that how instrumental perspective conducts the fantastic form producing the shocking and magical images; how it governs the binary frame of "Us" versus "Them."

The significance of the fetish discourse in the inversion of instrumental perspective may be summarized as follows: the

${ }^{3}$ Images illustrated Etienne Gaspard Roberton's phantasmagoria show (Paris, 1831), cited by Oliver Grau, "Remember the Phantasmagoria! Illusion Politics of the Eighteenth Century and Its Multimedial Afterlife," in MediaArtHistories (Cambridge: MIT Press, 2007), pp.137-161. 
collaborative relationship of "We" human-and-technology, within which the social character of our labor affirms itself, takes the form of a social relation between the products through the collaboration. The fetish operates relations, and supports the inversion in the process of transference of the use-value and exchange-value. It subordinates the collaborative relationship of "We" human-and-technology into the material one.

\section{INVAGINATION}

The collaborative action of "We" human-and-technology criticizes that the inversion of instrumental perspective uses the fetish of relations as a disciplinary instrument, in order to govern our sensibility. The critique provides the key for selfcriticism. It remembers that "Let us reexamine the question of man. Let us reexamine the question of cerebral reality, the brain mass of humanity in its entirety whose affinities must be increased, whose connections must be diversified and whose communications must be humanized again [16]." The political and aesthetic friendship of "We" human-and-technology provides one insight beyond knowledge based on logic of opposition. It reminds us of circle "to look at scientific enquiry from the perspective of the artist, but to look at from the perspective of life [17]." In circle, truth is nothing but a mobile army of metaphors. If it did, there are no secure standards of truth, but many truths in the performing of collaborative action of "We" human-and-technology.

\section{REFERENCES}

[1] M. Foucault, Discipline and Punish, New York: Vintage Books, 1955, p. 191.
[2] G. Deleuze, "Postscript on the Societies of Control," October 59, New York: MIT Press, 1992, pp. 4-5.

[3] H. K. Cho and J. S. Yoon, "Performative art: The Politics of Doubleness," Leonadro, Vol 42. Issue 3, New York: MIT Press, 2009.

[4] M. Foucault, Ibid., 199.

[5] S. Turkle, Evocative Objects: Things We Think With, Cambridge: MIT Press, 2007, p.5.

[6] F. W. Nietzsche, Nietzsche: Thus Spoke Zarathustra, Cambridge: Cambridge University Press, 2006, p. 49.

[7] M. Heidegger, The Question Concerning Technology and Other Essays, New York: Harper \& Raw, Publishers, Inc., 1977, p.19.

[8] J. Lacan, Encore, The Seminar of Jacques Lacan Book XX., New York: W.W. Norton \& Company, 1999, p.97.

[9] K. Marx and F. Engels, The German Ideology, New York: International Publishers Co., 1970, p.47.

[10] K. Marx and F. Engels, Ibid., 47.

[11] K. Marx and F. Engels, Ibid., 47- 48.

[12] H. K. Cho and J. S. Yoon, "Toward a new desigh philosophy of HCI: Knowledge of Collaborative Actin of "We" human-and-technology," LNCS 8004, Springer, 2013, pp. 32-40.

[13] K. Marx, "The fetishism of commodities and the secret thereof," in Capital-A Critique of Political Economy, New York: International Publishers Co., 1970, p. 77.

[14] K. Marx, Ibid., 83.

[15] O. Grau, "Remember the Phantasmagoria! Illusion Politics of the Eighteenth Century and Its Multimedial Afterlife," in MediaArtHistories, Cambridge: MIT Press, 2007, pp.137-161.

[16] F. Fanon, The Wretched of The Earth, New York: Grove Press, 2004, pp. 237-238.

[17] F.W. Nietzsche, Nietzsche: The Birth of Tragedy and Other Writing, Cambridge: Cambridge university Press, 1999, p.192. 